\section{Northern Balinese Nickname System}

I Dewa Putu Wijana

Department of Languages and Literatures Universitas Gadjah Mada

Idp_wijana@yahoo.com

\begin{abstract}
This paper is intended to describe the Northern Balinese nick name system with focus of attention on the forms and their relation with the owner's real names, and various references and their connection with the extralinguistic facts of the person they refer to. By using corelational method between the nick names and the owner's real names, and between the references and physical, behavioral, and historical realities of the person they denote to, It is found that there are at least three relation types that hold between the nick names and the real names, namely arbitrary, formal, and extralinguistic relation type; The nick names semantically refer to various entities, such as animal and its excrement, physical and mental characteristics, illness, fruit and food, childhood expressions, personal figures, and important events. All of these referents are essentially reflections of cultural realities of the Nothern Balinese community members' interaction in their new places.
\end{abstract}

Keywords: nick name, real name, reference

\title{
INTRODUCTION
}

It was approximately in the early fourties, when the agricultural lands in the southern and eastern of Bali areas were getting narrower and narrower, a lot of farmers in these areas, began to move to Singaraja for the sake of better livelihood because not many works are left to do in the villages. In their new place, some of the new comers still maintain their former profession as famers because there are still enough land to cultivate, or fishermen as accidently the new place is situated in the north of Bali coastal area. And, a lot of new comers could not stand with their old profession. They turn their former profession to become traders, labourers, craftmans, and various services. In the new places Singaraja, they mixed with other new city dwellers of either the same or different religions, such as Javanese, Madurese, Bugis, Chinese, etc. Singaraja, the first province capital , was then becoming more crowded, and as well as the sea port before the Balinese capital was moved to Denpasar. The long and intensive contact between the sub or different ethnic groups made their younger generations adopt a new Balinese variety which is recently called the Nothern Balinese dialect or Buleleng Dialect which is significantly different from ones found in other places, such southern Bali (Klungkung and Karangasem), Western Bali (Jembrana), Middle Bali (Tabanan). The characteristics of Buleleng dialect and the close intra and inter ethnic contact can be clearly seen from many linguistic aspects, especially those are used in informal speech situations. This paper will surely impossible to discuss all linguistic aspects that characterize the Northern Balinese dialects and its communal inter relationship. Accordingly, the discussion will be focused on the use of nick names that constitutes one of the most interesting problems to describe that up till now has not got serious attention from Balinese researchers. Two main problems which will be addressed are: 1) the forms of the nick names and their relation types with the owner's real names or its physical characteristics; and 2) referents denoted by the nick names, and the reasons underlying the denotation.

\section{LITERATURE PREVIEW}

So far, discussions on the use of personal names are mostly related with real names. Allan (1986, 7071) states that different from common words, personal name as part of proper name does not have sense. No ene can describe the meaning of someone's name. The semantic features contained in the personal names are putative, and this is totally different from ones contained in common words. Accordingly, unlike common words, personal names mostly can not be translated into other languages. Meanwhile, Uhlenbeck (1982, 370-399) in spite of describing the process of naming, he also deeply classifies Javanese personal names based on type, sex and social status of the name's owners. 
Still about Javanese personal real names, studies carried out by Widodo $(2016,299-306)$ and Sahayu (2014) has described at length constructing and semantic elements of the names, and its roles and functions in strengthening and sustaining the Indonesian cultural characteristics. Meanwhile, concerning the Javanese nick names, the discussions are mostly done in connection with Javanese address terms (Supardo, 1995, 102). The use of nick names is superficially stated as one way of the Javanese addressing the interlocutor, and he only finds 3 kinds of referents, animal, puppet, and utensil used for this activity without any effort to deepen various interesting problems consisted in the nick names. As such, this paper will try to describe and resolve more profoundly two nick name problems have been mentioned above.

\section{THEORETICAL FRAME WORK}

Up till now, there is not any expert can count exactly the number of styles or registers possibly exists in one language. Based on its degree of formality, Joss $(1962,13)$ for instance differentiates 5 types of linguistic style existing in any language. Those are frozen, formal, consultative, casual, and intimate. No matter how many styles may be identified to be found in any language by the experts, they can simply be distincted into two types, i.e formal and informal style respectively. Formal style is a language variety used for conducting formal activities, such as language used for lecturing, delivering speech, writing official letters, etc. Conversely, informal style, is a language variety used to communicate in informal occasions, Such as selling and buying, bergaining, chatting, joking, and others. Commonly, the variety is used among people who are already tied up by intimate relationship. Here, the colloquial forms of expressions are symbolizing types of relationship that hold between the interlocutors. In line with these language style, and as far as personal names are concerned, there should be at least two kinds of name that used to be exploited in verbal communicative activities, namely real names and nick name. Real name or formal name is a name used in formal occassions. This kind of name appears in official documents, such as citizen card, birth or academic certificates, school report books, etc. Meanwhile, nick names are never used in such official documents. This kind of name is an informal, often humorous, name of person that is connected with their real name, their personality, or appereance, or something they have done (Horby, 2010, 995). As part of cultural facts, the language practise in which the use and creation of nick name is integrated, are inseperable from the influence of extralinguistic factors, such as events and history, customs, natural environments, etc. happens and finds in the community. From communicative theory, names are essentially semantic system of certain culture or subculture (Fiske, 2004, 32). Based on this assumption, the unique characteristics of Balinese culture, more specifically the interrelations of ethnic or community groups in the Northern Bali, will make the creation of nick names in this place to some extend different from ones found in other parts of Bali.

\section{RESEARCH METHOD}

All data presented in this paper constitute my friends and my play mates' nick names, and nick names of some people living in Singaraja, especially in Banjar Kaliuntu and Kampung Anyar, two among many villages located in Singaraja coastal areas. There are also some nick names of my friends in senior high school in this city. The data are further classified based on forms and their relation type with the real or formal names, and their semantic references and the reasons underlying the nick naming practises.

\section{FINDINGS AND DISCUSSION}

\section{Forms and Their Various Relation Types}

Every Balinese person living in Northern Bali used to have nick names which are created by other people (play mates, close friends, family members, etc.) since early of his/her life time or when the person is already grown up. Its creation is motivated by various purposes, such as comemoration, insultion and offence, intimation, kidding, etc. It is often the case that this informal names are more familiar among the community, close mates and the family mambers. As such, this funny names often functions as initial information before, someone can identify the owner's of the real names. Generally speaking, the forms of Balinese nick names constitutes word or phrases. The words consist of two up two three syllables, while the phrases consist of two up to three words. This kind of name are much shorter than the Balinese real names in general that consist article I or Ni for woman or girl belonging to sudra caste added with birth order name such as Putu, Made, Nyoman, or Ketut and 
followed by the real name which possibly consists of one or more words. See (1) to (5) below, and compare them with the formal names presented in the right side. Henceforth, only the nick names are becoming focus of discussion.

(1) Subali 'puppet character in Ramayana Epic' > I Dewa Putu Suarsa

(2) Sotong 'meaningless personal name' > I Dewa Putu Gunawan

(3) Belekok, Kokokan 'stork' > 'I Dewa Made Mawan'

(4) Sere Pengit 'rotten prawn paste' > I Ketut Slamet'

(5) Ngkah Pengit 'bad smell of exhaled breath' > 'I Dewa Made Wardana'

Examples (1), (2), and (3) are polysyllabic words, and (4) and (5) are phrases consist of two words. In more informal occassions, the nick name words can undergoes shorthening process, and only the last syllables left, as shown by (6) to ( 9 ) below:

(6) Coco > Co 'meaningless personal names'

(7) Pondal > Ndal 'short'

(8) Sotong > Tong 'guava'

(9) Kacang Goreng > Reng 'fried peanut'

The nick names can also undergoes phonological substitution (10), (11) and (12), syllabic permutation (13) and (14), even total back formation (15).
(10) Sirat > Seret 'meaningless personal names'
(11) Pondal > Pondil 'short'
(12) Tapak > Tapik 'meaningless personal names'
(13) Korocek > Cekoro 'meaningless personal name'
(14) Curek > Rekicu > hejut 'runny ear'
(15) Bongol > Longob 'deaf'

It is also often the case that the nick name is intended to name an older and a younger brother in the family. A careful investigation toward the relation between the nick names and the real names or the physical characteristics or the state condition of the person they refer to, reveals the following several relation types.

\section{Arbitrary Relation Type}

Many of the nick names created for someone do not have any relation with the owner's real names. In this matter, all the nick names constitute meaningless personal names, while the real names might contain putative meanings, such as seen in the following (16) to (19):
(16) Jerotot: Suarja
(17) Kacret: Sukayadnya, Bastila
(18) Tapak: Sumanika
(19) Keprik: Tantra

Jorotot, Kacret, Tapak, and Keprik are words that can not be found in any Balinese Dictionary. Meanwhile, the real name Suarja putatively means 'glorious prosperity', Sukayadnya 'happy holly sacrefice', Tantra 'One of Budhist streams', Sumanika 'this is good', Bastila 'name of a place'.

\section{Formal Relation Type}

No matter how mixed the new comers live with each other, several of them live close to their family relatives of coming from the same village to form enclaves. So, there are enclaves of people from Klungkung, Bangli, Karangasem, Bugis, Madura, etc. The enclaves are commonly situated close to their working places. Because of their settlement pattern, some of the new comer groups still maintain their own language or dialects. This lingusitic maintenance can influence the creation of nick names. For example the migrants come from Bugbug, one of Karangasem villages, call their children with voiceless glottal stop additional ending to the real names ended with vowel, such as shown by (20) to (24) below. The phonogical transcription of the nick names are placed inside the brackets [ ]: 

(20) Mingguk: Minggu $>$ [minggu + ?] $>$ [minggU?]
(21) Tangguk: Tanggu $>$ [tanggu + ?] $>$ [tanggU?]
(22) Sradak: Sariada > [sariadd + ?] > [sariada?] > [Sradak]
(23) Krinuk: Krinu $>$ [krinu + ?] $>$ [krinU?]

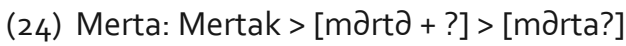

In my data collection, only one example found which is slightly different from what is practised by the Bugbug people. The nick name is not a phonotactic process in which [ə] does not change into [a]. So, Merta does not become Mertak, but Mertok. Consider (25) below:

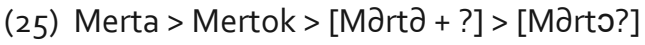

The other possibility of the formal relation type is the nick names are the acronyms of the real names, such as shown in (26) and (27).

(26) Dede > Dewa Made (Novan)

(27) Do Dan De > I Dewa Made (Artha)

\section{Extralinguistic Relation Type}

In extralinguistic relation type, the relation is relied on various non linguistic factors which hold between the referent of the nick name and the person it refers to. The relation can be related to physical and behavioral similarity, or historical relatedness existing between them. To make this clearer, see (28) to (31) below:

(28) Sere Pengit 'rotten prawn paste'

(29) Enggung 'big frog'

(30) Kejing 'bird legs and its claw'

(31) Aunteng 'Children utturance for Yang milu ke peken 'I joint you going to market'

Sere pengit "rotten prawn paste' is given to someone because of his father is a spice trader. And one of the main merchandises that brings significant benefit is prawn paste. Enggung 'large frog' is given to a kid who has big voice like a frog. Kejing literally means 'bird leg and claw'. This word is especially associated with tall types of bird such as stork, flamingo, etc. As such, the nick name is usually attached to a tall person. Aunteng is an infancy imperfect expression of Balinese utturance "Yang milu ke peken" 'I come along to the market' as a daily request to her merchant parents. This expression then become her nick names given by her relatives, neighbours and the whole clan community members. The following section is discussion concerning the referents of the Balinese nick names and their various extralinguistic relations with the person they refer to. In similarity relation type, for the purpose of remeberance ease, the nick names are often created on the basis of family relation, such as between or among siblings or child(ren) or parent (s). For example, if someone gets nick names sotong 'guava', his child would be possible to be called apel 'apple'. Like wise the nick name of Kano 'small boat' is given to a young child because his father's nick name is jukung 'traditional boat'. A girl is called by her nick name Tain Bebek 'dick shit' because her brother's nick name is Tain Siap 'chiken shit'. The following sections will discuss various kinds of referents used to create nick names, and the reasons that underly their creations.

\section{Referents of Nick Names and Their Reasoning Creation}

A careful examination toward the data collection is able to reveal that there are various kinds of referent commonly used to create nick names. Those referents includes animal and its excrement, physical characteristics, puppet characters, Gamelan Sound, food, fruit, and seed, disease and others.

\section{a. Animal and Its Excrement}

Animal and its excrement constitute important sources of nick names in North of Bali. The former agricultural and farming livelihood of the people are strongly influenced the creation of the naming. The animals used to find in the rice fields, such as Blekok or Kokokan 'stork', Enggung 'big frog' and katak gadang 'green frog', Tain Siap 'chiken shit' and Tain Bebek 'duck shit' are used to 
nick name individuals based on various similarities. Blekok or Kokokan is an onomatopoeic bird name originated from the animal's sound. However, the nick name given is not to be based on such a matter, but on the physical characteristics of the person and the animal, i.e. tall. Different from blekok and kokokan, Tain Siap and Tain Bebek which are in informal occasion to be shortened as Siap and Bebek are given to the owners because of the disease suffered by them in their childhood. The owners often get abses in their head which is similar to chiken shit, and his sister is given Tain Bebek 'duck shit' for the same diasease. It certainly can not be denied that Bebek is also possible to be used to nick name someone who has a mouth similar of the animal's beak. Three people of belonging to the same extended family member are respectively given nick names which are semantically close to each other. All refer to small birds of the same species, i.e. Perit 'sparrow', Petingan 'a sort of sparrow', and Bondol 'white headed sparrow'. Enggung is a Balinese word for referring to 'big frog'. This nick name is given for a small boy whose voice is big which is equal to the sound produced by the animal. Blengur is a Javanese borrowing which refers to 'young swan' for nick naming a man with protruded forehead. The nick name can also be based on the behavioral and physical similarities of the person. For example, Katak Gadang 'green frog' is given to a big bodied boy who everyday used to wear green shirt. Finally, the nick name is also possible involving a part of the animal body. Kumis Bikul ' mouse whisker' is used to name someone of the similar facial characteristics. Kejing 'bird leg and claw' is associatively used to summoned a tall bodied person. Because of movie film influence, forrest animal, i.e. King Kong is also found among animal nick name to call big bodied individuals.

\section{b. Physical and Mental Characteristics}

Several Balinese adjectives that all associate with body and body part conditions are commonly used to create nick names. Those adjectives for instance are Pondal 'short', Mokoh, Lantang 'long', Tulik (from the acronym of Putu (first birth ordered child) and Cilik 'small'), Lumbang 'big, large', Tembem 'chubby' and Kelet 'scar'. As suggested by the their meanings, Pondal, Mokoh, and Lantang are respectively the nick names of individuals having short, big, and tall body. Meanwhile Culik for someone who has a small one. All of these are different from Lumbang and Tembem because these last two nick names are used to refer to body part of some one who ownes large or big ears, and chubby cheeks. Subsequently, Kelet is a personal nick name of someone with visible scar in certain parts of his/her head. Lengar is given to someone having bold head, and Sengat to someone with imbalanced visual eye sight. Finally, Pencor and Pengkoh are used to nick name a limp person. In the data collection, only one example, i.e. Kucluk 'mad' is used to nick name. Kucluk is a Javanese borrowing to refer to 'mad'.

\section{c. Illness}

Close to physical defects, illness suffered by someone can also become logical reasons of nick naming practices. Someone who suffers Curek 'running ear' illness in the childhood, can be summoned by the illness untill she/he is grown up. This illness can metonymically be associated with the behavioral consequence of the people suffereing those illness, namely Bongol 'deaf' and its back formation Longob 'deaf' or Lengkeng 'difficult to be called' as his/her other nick name summons. Because of the Javanese influence, the Javanese words Kopok 'running ear' or its slight modification Popok are used for nicknaming without any different sense.

\section{d. Fruit and Food}

Although it is not always clear the reasons underllie the nick naming, there are some people get nick names related to popular food such as tempe 'soy bean cake' and fruit sotong 'guava'. And, for the ease of remembering, her sister is named tahu 'bean curd'. While, the person's son getting Sotong is named apel 'apple'. Other fruits used for nick naming are Tingkih 'oily fleshed fruit, Aleurites moluccana'. The most interesting is the nick name given to We Bekul 'Aunt Bekul' which in later development becoming We Nekul. This name is created because the old woman used to sell food under a big "bekul" tree grown in front of the community centre. The tree itself is already chopped down now. Bekul is a Balinese word for 'big thorned and small seeded fruit tree'. Kentang 'potato' is another nick name for a Balinese person without any clear reason.

\section{e. Gamelan and Performance}

Balinese Gamelan and its traditional performance (dance or play) had been so popular in the past three decades. Therefore, some Balinese people are very familiar with certain Gamelan rythms. 
Accordingly, one or both of the child's parents or grand parents use them for rearing or entertaining their children or grand children. This rearing habit then made possible the child(ren) to be nick named by the Gamelan rythm. Kelentung, Dodande, Dog Nang, Nong Nong, and Kenong are the examples for this matter. Tupeng is a Balinese word for 'mask'. Balinese traditional play uses many kinds of mask, one of which is Tupeng Tuwa 'old faced mask'. Tupeng Tuwa which is shortened to be Tupeng is a nick name for a person of similar facial condition as well as Barong 'Balinese monster mask' for calling big eyed little boy. Eventhough it is performed in very simple way, leather puppet is also very pupular among the Nothern Balinese because of the rareness of free entertainment. This performance is held in occasion of wedding or birth ceremonies. Subali, one of powerful bad ape characters in Ramayana epic, and Tonglang, an indigenous Balinese clown and Malen, Balinese version for Javanese and Sundanese Semar (see Covarrubias, 1973, 224-225), are consecutively used to name Balinese person on the basis of attitudinal characters and similar physical characteristics.

\section{f. Childhood Expressions}

Because the nature of language acquisition in their early childhood, most of the children will experience speech impedements in producing certain linguistic sounds. Some of them are very unique that they will become focus of attention, laugh, and insultion of their play mates and surround adults because most of their friends of the same age do not linguistically perform the same behaviour. The funny and unique expressions then become the children nick names. For example Buut, Aunteng and Chinoatiacung. Buut is a nick name given to a young boy that can not properly expressed jukut 'vegetable' when everytime he wants to buy porridge for his morning breakfast. His verbal behaviour makes the porridge seller and other people confused. Aunteng is an expression of a little Nothern Balinese girl to mean Yang milu ke peken 'I follow yo going to the market'. Because of its uniqueness, the adults used the expression for nick naming the little girl, and the name is still used untill she is grown up. Cinaatiacung is an unperfect expression of a Balinese phrase Cina mati lacur 'a poor Chinese dead' when he observes that there is a big difference funeral procession between a poor and a rich Chinese. The rich Chinese uses music parade, while the poor does not.

\section{g. Personal Figures}

Someone's nick names might also be taken from other personal names which are based on certain reasons, such as bad economic condition, physical characteristics, psychological condition, etc. For example, Kumangmang and Aloha are two of mad people in Singaraja in the middle sixties, and their names are given to someones because of physical and behavioral resemblances. Ibrahim and Wakdul (the short form (acronym) of Wak Abdullah), and Saleh are typical moslem names. Moslem is commonly associated with Arab. So, Arab is also found for nick naming someone on the basis of physical similarities. These names are also taken for insulting someone with similar physical characteristics regardless the glorious meaning of such names. Cik or Cike is an address term for a chinese, and it is given to someone of having physical similarities. Singaring and his wife Botol are given metonymically to the one person on the reasoning basis of their miserable life and economic condition.

\section{h. Important Events}

Important event which coincides with someone birth can also be the reason of the nick name creations. In the middle of seventies, Singaraja was shaken by witch doctor sexual horrasment scandal that is well known as Dukun Cabul Scandal. Because the baby boy was born at the same time as the witch doctor's trial, the baby boy was then named Cabul. This nick name is still used untill the bairn is grown up. Tuk Tuk Wo is door to door commercial visit program hosted by the late comedian actor Taufik Savalas. This program is under sponsor of a detergent product. One boy who was by chance born coincides with this program was given nick name Tuk Tuk Wo.

\section{CONCLUSION}

Any language has a number of styles, and each style plays the same important role as the others. As far as informal style is concerned, this linguistic style is characterized by the use of various properties, one of which is nick name. This style device is exploited by the community members for strengthening solidarity among them which are reflected in various linguistic activities, such as joking, insulting, 
chatting, etc. The forms of nick name may consist of two words that can be shortened at maximum into one syllables, i.e. the final syllable of the nick name. The nick names may constitute meaningless expressions, or words that have formal relation with the real names through various linguistic processes, such as deletion, addition, and sound substitution. The nick names can also be meaningful expressions of various kinds of referents, such as animal and its excrement, physical and mental characteristics, Illness, Fruit and Food, childhood expressions, personal figures, and important events. These expressions show many kinds of relations (physical, historical, behavioral, etc.) with the owners of the nick name.

\section{REFERENCES}

Allan, Keith. 1986. Linguistic Meaning, Vol. 1. London: Routledge \& Kegan Paul.

Covarrubias, Miguel. 1937. Island of Bali. Hongkong: Periplus.

Fiske, John. 2004. Cultural and Communication Studies. Jakarta: Jalasutra.

Hornby, A.S. 2010. Oxford Advanced Learner's Dictionary. Oxford University Press.

Joss. Martin. 1962. The Five Clocks. Mouton Co.

Sahayu, Wening. 2014. Nama Diri Masyarakat Jawa. Yogyakarta: Program Pascasarjana Universitas Gadjah Mada.

Supardo, Susilo. 1995. Sistem Sapaan Bahasa Jawa Dialek Banyumas. Master Thesis, Gadjah Mada Ubiversity.

Uhlenbeck, E.M. 1982. Kajian Morfologi Bahasa Jawa. Translated by Soenarjati Djajanegara. Jakarta: Djambatan.

Widodo, Sahid Teguh. 2016. "Nama Diri Orang Jawa sebagai Bentuk Penguatan Budaya Etnik di Indonesia". Isu-isu Mutakhir dalam Kajian Bahasa dan Sastra. Yogyakarta: Interlude.

\section{LIST OF NOTHERN BALINESE NICK NAMES IN ALPHABETICAL ORDER}

Aloha 'personal name'
Apel 'apple'
Arab 'Arab'
Aunteng 'I join you to the
market'
Barong 'Balinese monster
mask'
Bekul 'big thorned tree'
Belekok 'stork'
Bondol 'white headed
sparrow'
Bongol 'deaf'
Botol 'persoal name'
Buut 'vegetable'
Cabul 'pornographic'
Cedur 'meaningless
expression'
Cekoro 'meaningless
expression'
Cike 'Adress term for
Chinese person'
Cinoatiacung 'poor
Chinese'

Coco 'meaningless
expression'
Culik 'sound alternation of
Tulik'
Curek 'runny ear'
Dede 'acronym of Dewa
Made'
Dodande 'Gamelan Sound,
acronym of Dewa Made'
Dog Nang 'gamelan sound'
Enggung 'big frog'
Ibrahim 'personal name'
Jerotot 'meaningless
expression'
Jukung 'small boat'
Kacang Goreng 'fried
peanut'
Kacret 'meaningless
expression'
Kano 'Canoe'
Katak Gadang 'green frog'
Kejing 'avian leg and claw'
Kingkong 'King Kong, big
monkey'
Kacret 'meaningless expression'
Keprik 'meaningless
expression'
Kelentung 'gamelan sound'
Kelet 'scar'
Kentang 'potato'
Kenong 'small gong'
Kokokan 'stork'
Kopok 'runny ear'
Korocek 'meaningless
expression'
Kucluk 'mad'
Krinuk 'meaningless
personal name'
Kumangmang 'personal
name'
Kumis Bikul 'mouse
whisker'
Lantang 'long'
Lengar 'bold'
Lengkeng 'difficult to be
called'
Longob 'deaf'


Lumbang 'big (ear)'

Malen 'puppet clown

character'

Mertak 'life'

Mingguk 'Sunday'

Mokoh 'big, fat'

Ngkah Pengit 'bad smell

exhaled breath'

Nekul 'sound alteration of

Bekul'

Nong-nong 'gamelan

sound'

Pencor 'limp'

Pengkoh 'limp'

Perit 'sparrow'

Petingan 'sort of sparrow'

Popok 'runny ear'

Pondal 'short body'
Pondil 'short body'

Rekicu 'runny ear'

Sere Pengit 'rotten prawn

paste'

Seret 'meaningless

expression'

Sengat 'imbalenced visual

eye'

Singaring 'personal name'

Sirat 'meaningless

expression'

Sotong 'guava'

Sradak 'Essence'

Subali 'puppet character in

Ramayana epic'

Tahu 'bean curd'

Tain Siap 'chiken shit'

Tain Bebek 'duck shit'
Tangguk 'end'

Tapak 'meaningless

expression'

Tapik 'meaningless

expression'

Tembem 'chubby'

Tempe 'soya bean cake'

Tonglang 'puppet clown

character'

Tulik 'acronym of Putu Cilik 'small Putu'

Tuk Tuk Wo 'commercial

door to door television

program

Tupeng (tuwa) '(old

charactered) mask'

Wak Dul 'personal name' 